
Paleoclimatology

\author{
RESEARCH ARTICLE \\ 10.1029/2020PA004088 \\ Key Points: \\ - Paleosalinities of Last Glacial \\ Maximum (19-26 ka) North Atlantic \\ Bottom waters are 3.41-3.99 $\pm 0.15 \%$ \\ higher than modern values \\ - New paleosalinities support \\ expansion of salty, southern sourced \\ water displacing fresher, northern \\ sourced water in the Last Glacial \\ Maximum (LGM) deep Atlantic \\ - Paleosalinities are more precise \\ when from porewater densities \\ measured on ship from cores that \\ span the LGM porewater chloride \\ maximum
}

Supporting Information: Supporting Information may be found in the online version of this article.

Correspondence to:

K. Homola,

khomola@uri.edu

Citation:

Homola, K., Spivack, A. J., Murray, R. W., Pockalny, R., D'Hondt, S., \& Robinson, R. (2021). Deep North Atlantic Last Glacial Maximum salinity reconstruction. Paleoceanography and Paleoclimatology, 36, e2020PA004088. https://doi.org/10.1029/2020PA004088

Received 14 AUG 2020 Accepted 16 APR 2021
(C) 2021. American Geophysical Union. All Rights Reserved.

\section{Deep North Atlantic Last Glacial Maximum Salinity Reconstruction}

\author{
Kira Homola ${ }^{1}$ (i), Arthur J. Spivack ${ }^{1}$, Richard W. Murray ${ }^{2}$ (), Robert Pockalny ${ }^{1}$, \\ Steven D'Hondt ${ }^{1}$, and Rebecca Robinson ${ }^{1}$ (D) \\ ${ }^{1}$ University of Rhode Island Graduate School of Oceanography, Narragansett, RI, USA, ${ }^{2}$ Woods Hole Oceanographic \\ Institution, Falmouth, MA, USA
}

\begin{abstract}
We reconstruct deep water-mass salinities and spatial distributions in the western North Atlantic during the Last Glacial Maximum (LGM, 19-26 ka), a period when atmospheric $\mathrm{CO}_{2}$ was significantly lower than it is today. A reversal in the LGM Atlantic meridional bottom water salinity gradient has been hypothesized for several LGM water-mass reconstructions. Such a reversal has the potential to influence climate, ocean circulation, and atmospheric $\mathrm{CO}_{2}$ by increasing the thermal energy and carbon storage capacity of the deep ocean. To test this hypothesis, we reconstructed LGM bottom water salinity based on sedimentary porewater chloride profiles in a north-south transect of piston cores collected from the deep western North Atlantic. LGM bottom water salinity in the deep western North Atlantic determined by the density-based method is $3.41-3.99 \pm 0.15 \%$ higher than modern values at these sites. This increase is consistent with: (a) the $3.6 \%$ global average salinity change expected from eustatic sea level rise, (b) a northward expansion of southern sourced deep water, (c) shoaling of northern sourced deep water, and (d) a reversal of the Atlantic's north-south deep water salinity gradient during the LGM.
\end{abstract}

Plain Language Summary Twenty thousand years ago, the atmosphere had a much lower temperature and contained less insulating carbon dioxide $\left(\mathrm{CO}_{2}\right)$ gas than it did even before the human induced $\mathrm{CO}_{2}$ rise of the last centuries. Confirming if the carbon "missing" from the atmosphere 20,000 years ago was stored away in the deep ocean will help us predict where the carbon humans add to the atmosphere will end up over the next few millennia. We find the temperature and amount of salt (salinity) in today's waters by measuring them directly, but to find them in the past ocean we measure chemical compounds that are buried over time in the seafloor. In this study, we measure the density of water collected from the north Atlantic seafloor to estimate the past salinity. Our results support previous findings that 20,000 years ago the deep Atlantic was filled with more carbon-rich water that sank from the surface in the Southern Ocean than in today's Atlantic, accounting for up to two-thirds of the carbon "missing" from the atmosphere 20,000 years ago.

\section{Introduction and Background}

Meridional overturning circulation (MOC) is an important aspect of Earth's climate due to its associated heat flux and influence on atmospheric $\mathrm{CO}_{2}$ (see Schmittner et al., 2007 for a review). Salinity is central to understanding the $\mathrm{MOC}$ as it influences circulation via density gradients and is used to characterize water-mass distributions. In the modern Atlantic, northern sourced deep waters are saltier than southern, with separate northern and southern MOC cells (Talley et al., 2015). The northern cell of Atlantic MOC extends south of the equator, resulting in northward heat transport across the equator from the Southern Hemisphere (Robinson \& Stommel, 1959). The distribution and composition of Atlantic northern and southern sourced deep water-masses influence the global carbon inventory and can be constrained for the past ocean through historical reconstructions of water-mass geometry (Boyle \& Keigwin 1982; Schmittner \& Galbraith 2008).

Global climate has cycled between major glacial and interglacial modes over the past 33 Mya (Doney \& Schimel, 2007; Zachos et al., 2001), with changes in atmospheric $\mathrm{CO}_{2}$ concentrations highly correlated to climate variations over the past 730 ka (Petit et al., 1999; Siegenthaler et al., 2005; Sigman and Boyle 2000). The Last Glacial Maximum (LGM), 19-26 ka, with atmospheric $\mathrm{CO}_{2}$ concentrations $30 \%$ lower than preindustrial levels, is the most recent example in the geologic record of atmospheric $\mathrm{CO}_{2}$ change similar in 
magnitude to the anthropogenic change we are observing today (Clark et al., 2009; Mix et al., 2001; Peltier \& Fairbanks, 2006). As the absolute global abundance of salt in the ocean has been relatively constant over the past 3.2 Ma (Pilson, 2015), eustatic sea level $130 \mathrm{~m}$ lower during the LGM would have resulted in a $3.6 \pm 0.3 \%$ average salinity increase (Clark et al., 2009). Sedimentary pore fluid chloride, determined by $\mathrm{AgNO}_{3}$ titration, combined with diffusion modeling, has been used to infer LGM bottom water salinity at several sites in the Atlantic and Pacific (Adkins et al., 2002; Insua et al., 2014). Adkins et al. (2002) reported a $3.5 \pm 0.5 \%$ average and $4.2 \pm 0.5 \%$ relative range for salinity increase from the modern to the LGM among three Atlantic sites, with a north-south deep Atlantic salinity gradient opposite that of the modern. This salinity reversal, where southern sourced deep waters were saltier than deep water formed in the North Atlantic, is consistent with water-mass distributions inferred from models (Holloway et al., 2016; Kim, 2004). Low atmospheric $\mathrm{CO}_{2}$ and low temperatures are thought to have resulted in decreased precipitation and increased sea ice formation and brine rejection (Boyle 2002; Jansen, 2017). The LGM Southern Ocean was thought to have been net salinifying, rather than net freshening as in the modern (Galbraith \& de Lavergne, 2019). Expanded LGM ice sheets would have increased the salinity and volume of southern sourced deep water and the overturning rate of colder, fresher water in the North Atlantic (Galbraith \& de Lavergne, 2019; Holloway et al., 2016; Jansen \& Nadeau, 2016; Kwon et al., 2012; Negre et al., 2010). Salinity stratifying the deep ocean increases its thermal energy and carbon storage capacity, likely contributing to many observed climate variations including lower glacial atmospheric $\mathrm{CO}_{2}$ and Dansgaard-Oeschger events (Adkins et al., 2005; Bouttes et al., 2009; Schmittner \& Galbraith 2008). Accurate estimates of deep-water salinities during the LGM are thus critical to constraining MOC and understanding the ocean's role in climate change.

LGM deep water-mass distributions, properties, and overturning rates have been examined through measurements of benthic foraminiferal $\delta^{13} \mathrm{C}$ and $\delta^{18} \mathrm{O}$ (Graham et al., 1981; Curry \& Oppo 2005; Govin et al., 2009; Lynch-Stieglitz et al., 2007; Keigwin \& Swift 2017), paleosalinity (Adkins \& Schrag, 2003; Adkins et al., 2002; Insua et al., 2014; Matsumoto, 2017; Sijinkumar et al., 2016), and $\Delta^{14} \mathrm{C}$ of benthic foraminifera and uranium-thorium dated coral (Burke et al., 2015; Keigwin 2004). These results have been contextualized through numerous modeling studies (Clark et al., 2012; Cutler et al., 2003; Ferrari et al., 2014; Lund et al., 2011; Miller et al., 2012; Nadeau et al., 2019), including a comprehensive approach by Galbraith and de Lavergne (2019) that found density differences between northern and southern deep water formation regions can be used to predict changes in deep water-mass volumes. Matsumoto (2017) identified the potential boundary between LGM northern and southern cells from the transition of enriched (northern) to depleted (southern) $\delta^{13} \mathrm{C}$ of LGM benthic foraminifera (Curry \& Oppo, 2005). The southern cell likely expanded farther north and the northern cell shoaled, relative to present day, increasing the volume of carbon rich water in the deep ocean (Skinner, 2009). Two thirds of the observed atmospheric $\mathrm{CO}_{2}$ decrease during the LGM can potentially be explained by an increase in southern sourced deep water-mass standing volume, enhancement of the Southern Ocean biological pump, and expanded ice cover amplifying the air-sea disequilibrium (Brovkin et al., 2007; Ito \& Follows, 2013; Kobayashi et al., 2015). Keigwin and Swift (2017), using foraminiferal $\delta^{13} \mathrm{C}$ and $\Delta^{14} \mathrm{C}$, found evidence of a northern sourced, low-nutrient abyssal water-mass sinking below primary northern deep water, that could have contributed to increased convection and carbon sequestration.

The complex interface between the northern and southern overturning cells during the LGM remains unconstrained (Sigman et al., 2010). While Adkins et al. (2002) inferred LGM salinity near the formation regions of northern $\left(55^{\circ} \mathrm{N}\right)$ and southern $\left(50^{\circ} \mathrm{S}\right)$ sourced Atlantic deep water-masses, their values are significantly higher than expected from sea level change and represent an unconfirmed (Miller et al., 2015; Wunsch, 2016) salinity upper bound (Adkins et al., 2002). Resolving the critical LGM bottom water salinity gradient requires higher resolution data than previously available, both in terms of precision and number of sites. We determined paleosalinity at four sites along a north-south transect in the western North Atlantic (Figure 1) using our newly developed high-precision density-based method (Homola et al., 2020) to assess whether our sites' paleosalinities are consistent with a northward expansion of southern sourced deep water, shoaling of northern sourced deep water, and/or a north-south reversal of the Atlantic meridional deep water salinity gradient during the LGM. 


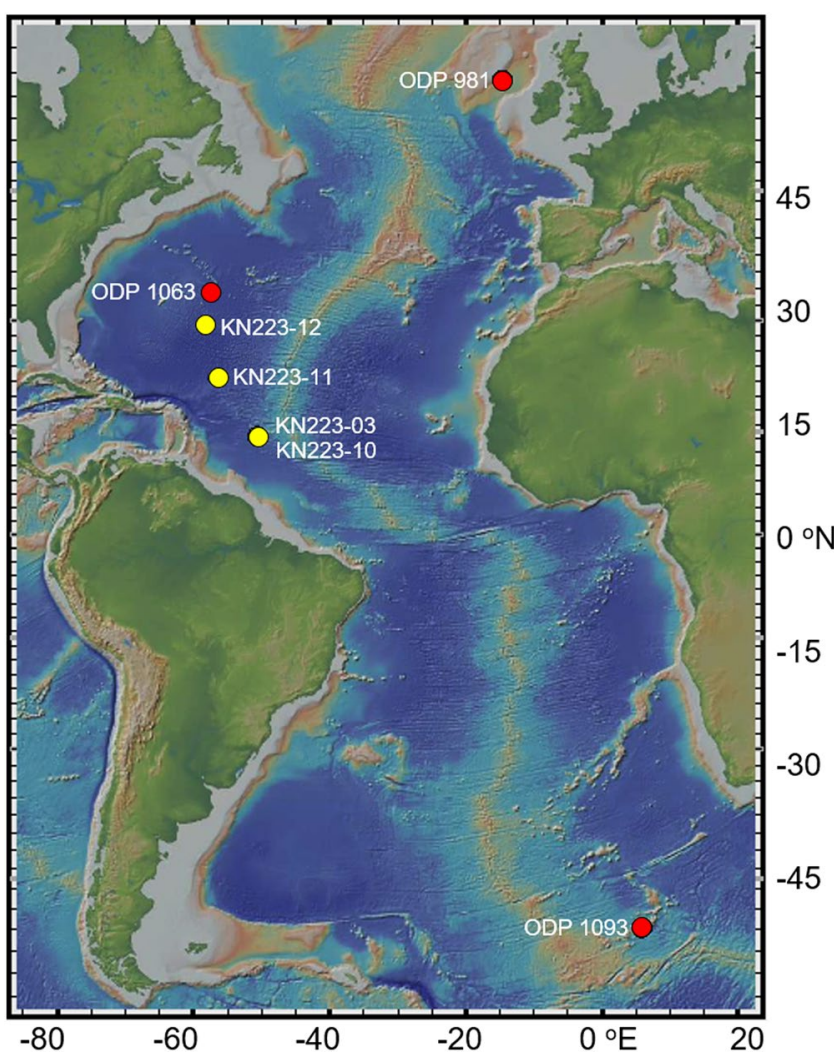

Figure 1. Locations of paleosalinity data from this study (KN223, yellow dots) and published Atlantic sites (Ocean Drilling Project (ODP, red dots) from Adkins et al. (2002).

\section{Methods}

We applied the density-based method of Homola et al. (2020) to determine in situ chloride concentration $\left[\mathrm{Cl}^{-}\right]$at four sites in the western North Atlantic. We generated a diffusion model similar to that developed by Adkins and Schrag (2003) to infer LGM bottom water salinity. The model determines a modern porewater $\left[\mathrm{Cl}^{-}\right]$profile based on the bottom water salinity over time scaled to fit measured porewater $\left[\mathrm{Cl}^{-}\right]$. The optimum input produces the best fit of the present-day profile output by the model to the measured profile.

\subsection{Site Description, Sample Collection, and Analysis}

Samples used for this study were collected from the $R / V$ Knorr during expedition KN223 (2014, cruise doi: 10.7284/900427) (see Figure 1 and Table 1) using a Niskin Bottle (CTD) and multicore (MC) for bottom water, and a long piston core (LC) for sediment and porewater (Curry et al., 2008). We analyzed cores collected from three locations (four sites) in the western North Atlantic (Figure 1) spanning $\sim 15^{\circ}$ latitude $\left(14.4^{\circ} \mathrm{N}-29.7^{\circ} \mathrm{N}\right), 7^{\circ}$ longitude $\left(50.6^{\circ} \mathrm{W}-57.6^{\circ} \mathrm{W}\right)$, and $\sim 1,100 \mathrm{~m}$ water depth (4,453-5,557 m) (Table 1). These sites span the likely LGM interface between northern and southern sourced deep water cells (Lynch-Stieglitz et al., 2007; Matsumoto, 2017; Oppo et al., 2018). Sediment thickness ranges from 98 to $100 \mathrm{~m}$ (Divins, 2003) overlying 40-90 Ma basement (Müller et al., 2008). Sediment at co-located sites 03 and $10(4,453 \mathrm{~m})$ is nannofossil clay with pelagic red clay, containing $25 \%-50 \%$ foraminifera, $30 \%$ siliceous ooze, up to $25 \%$ silt turbidites, and $5 \%$ radiolarian chert or diatom nannofossil ooze. Sediment at sites 11 and 12 (5,557 and 5,367 m) is pelagic red clay with less than 5\% silt and 5\% radiolarian chert. Core penetration ranged from 28.7 to $33.9 \mathrm{~m}$ below sea floor (mbsf). Porewater was extracted from core subsamples at $60 \mathrm{~cm}$ intervals with hydraulically driven titanium squeezers (modified after Manheim et al., 1974). Porewater and bulk sediment densities, $\mathrm{SO}_{4}{ }^{-2} / \mathrm{Cl}^{-}$ratio, alkalinity, $\mathrm{pH}$, dissolved inorganic carbon concentration, and formation factor (the ratio of electrical resistivity of the sediment to that of pore fluid) were measured onboard (data doi: 10.26022/ IEDA/111472). Dissolved cation concentrations $\left(\mathrm{Mg}^{+2}, \mathrm{Ca}^{+2}, \mathrm{~K}^{+}\right)$were measured after the expedition. Porosity $\Phi(z)$ was calculated based on bulk densities and porewater densities measured during KN223 and sediment density $\left(2,656 \mathrm{~kg} / \mathrm{m}^{3}\right)$ from published data measured at the nearest International Ocean Discovery Program (ODP) site (Erbacher et al., 2004; Pälike et al., 2013).

Measured profiles were smoothed using a second order robust-weighted local regression with a span of $60 \%$ depth (Cleveland \& Devlin, 1988). Uncertainty of each smoothed variable as a function of depth was assessed using a Monte Carlo approach. See Homola (2020) for details of analyses and the smoothing and error evaluation techniques.

$\left[\mathrm{Cl}^{-}\right]$is calculated from the measured density and the smoothed relative solute ratios $\Delta R_{i}$ with Equation 1 (see Table 2 for symbol definitions), based on the equation of state for standard seawater (Millero et al., 2008) and accounting for the effects of diagenesis on composition (Homola et al., 2020).

$$
\left[C l^{-}\right]=\frac{\rho_{\text {meas }}-\rho_{\mathrm{H}_{2} \mathrm{O}}}{a+\sum_{i} \Delta R_{i} A r_{i}-\rho_{\mathrm{H}_{2} \mathrm{O}} \sum_{i} \Delta R_{i} V_{i}}
$$

\subsection{LGM Bottom Water Salinity Reconstruction}

The model used to infer past bottom water $\left[\mathrm{Cl}^{-}\right]$is a one-dimensional time-dependent mass-balance equation that accounts for diffusion (Equation 2, see Table 2 for symbol definitions) (Adkins et al., 2002; Insua et al., 2014). 
Table 1

Atlantic Ocean Sites Where LGM Bottom Water Salinity has Been Measured, in This Study (KN223) or by Adkins et al. (2002) (ODP)

\begin{tabular}{|c|c|c|c|c|c|c|c|}
\hline \multirow[b]{2}{*}{ Study Site } & \multicolumn{4}{|c|}{ KN223 } & \multicolumn{3}{|c|}{ ODP } \\
\hline & 3 & 10 & 11 & 12 & 1063 & 981 & 1093 \\
\hline Latitude $\left({ }^{\circ} \mathrm{N}\right)$ & \multicolumn{2}{|c|}{14.401} & 22.785 & 29.677 & 33.686 & 55.477 & -49.976 \\
\hline Longitude $\left({ }^{\circ} \mathrm{E}\right)$ & \multicolumn{2}{|c|}{-50.623} & -56.518 & -58.328 & -57.615 & -14.651 & 5.866 \\
\hline Water depth (m) & \multicolumn{2}{|c|}{4,453} & 5,557 & 5,367 & 4,584 & 2,184 & 3,626 \\
\hline \multicolumn{8}{|l|}{ Density } \\
\hline$S(0,0)$ meas $(\mathrm{g} / \mathrm{kg})$ & $35.01 \pm 0.02$ & $34.97 \pm 0.02$ & $34.98 \pm 0.02$ & $35.00 \pm 0.03$ & & & \\
\hline$S(0,0) \bmod (\mathrm{g} / \mathrm{kg})$ & $35.21 \pm 0.01$ & $35.19 \pm 0.01$ & $35.15 \pm 0.02$ & $35.14 \pm 0.01$ & & & \\
\hline$S(0,-21.7 \mathrm{ka})(\mathrm{g} / \mathrm{kg})$ & $36.41 \pm 0.04$ & $36.59 \pm 0.05$ & $36.39 \pm 0.06$ & $36.43 \pm 0.05$ & & & \\
\hline$\Delta S_{\mathrm{bw}}(\%)$ & $3.41 \pm 0.12$ & $3.99 \pm 0.15$ & $3.51 \pm 0.16$ & $3.66 \pm 0.15$ & & & \\
\hline $\mathrm{z}\left(\max S_{\mathrm{pw}}\right)(\mathrm{mbsf})$ & $30.0 \pm 0.25$ & $32.0 \pm 0$ & $30.5 \pm 0.25$ & $32.0 \pm 0.25$ & & & \\
\hline \multicolumn{8}{|l|}{ Titration } \\
\hline$S(0,0)_{\text {meas }}(\mathrm{g} / \mathrm{kg})$ & $34.74 \pm 0.03$ & $34.66 \pm 0.06$ & $34.44 \pm 0.04$ & $34.26 \pm 0.08$ & $34.885 \pm 0.005$ & $34.945 \pm 0.008$ & $34.685 \pm 0.003$ \\
\hline$S(0,0)_{\bmod }(\mathrm{g} / \mathrm{kg})$ & $34.91 \pm 0.05$ & $34.76 \pm 0.05$ & $34.6 \pm 0.09$ & $34.51 \pm 0.1$ & & & \\
\hline$S(0,-21.7 \mathrm{ka})(\mathrm{g} / \mathrm{kg})$ & $36.06 \pm 0.09$ & $35.51 \pm 0.06$ & $35.74 \pm 0.08$ & $36.21 \pm 0.07$ & $35.83 \pm 0.03$ & $36.1 \pm 0.1$ & $37.08 \pm 0.17$ \\
\hline$\Delta S_{\mathrm{bw}}(\%)$ & $3.29 \pm 0.25$ & $2.16 \pm 0.18$ & $3.29 \pm 0.23$ & $4.95 \pm 0.18$ & $2.7 \pm 0.1$ & $3.3 \pm 0.3$ & $6.9 \pm 0.5$ \\
\hline $\mathrm{z}\left(\max S_{\mathrm{pw}}\right)(\mathrm{mbsf})$ & $30.5 \pm 0.5$ & $32 \pm 1$ & $30.5 \pm 1.5$ & $31.5 \pm 1.25$ & 38 & 25 & 57 \\
\hline Sediment thickness (m) & \multicolumn{2}{|c|}{100} & 100 & 98 & & & \\
\hline Sediment density $\left(\mathrm{kg} / \mathrm{m}^{3}\right)$ & \multicolumn{2}{|c|}{2,656} & 2,659 & 2,661 & & & \\
\hline Core penetration (mbsf) & 28.7 & 33.9 & 28.2 & 28.8 & & & \\
\hline
\end{tabular}

Note. Salinities for present day from smoothed measured, $\mathrm{S}(0,0)$ meas, and modeled, $\mathrm{S}(0,0)$ mod [Cl-]; LGM, $\mathrm{S}(0,-21.7 \mathrm{ka})$, from the diffusion model boundary condition; and their relative difference $\Delta$ Sbw are shown from the density and titration methods. Depth below seafloor of the porewater [Cl-] maximum from the best-fit model output, corresponding to the LGM bottom water salinity maximum, is shown for each profile.

$$
\phi(z) \frac{\partial\left[C l^{-}\right](t, z)}{\partial t}=\frac{\partial}{\partial z}\left(\frac{D(z)}{F(z)} \frac{\partial\left[C l^{-}\right](t, z)}{\partial z}\right)
$$

The chloride diffusion coefficient $D(z)$ varies with temperature and salinity. $D(z)$ is calculated from the published diffusion coefficient for chloride in seawater $D(0)$ (Li \& Gregory, 1974), the measured bottom water temperature at our site, and the published temperature gradient at Sites 03 and 10 (Erbacher et al., 2004) (see Supporting Information S1 for values and equations used). The effect of the published diffusion coefficient's uncertainty on the model output is accounted for by running the model with three different values of $D(0)$ : the published value and that value $\pm 5 \%$. Porosity and formation factor are included explicitly in Equation 2 (Homola et al., 2020; Insua et al., 2014) rather than being approximated as part of an effective diffusion coefficient that is calculated based on the depth of the measured porewater $\left[\mathrm{Cl}^{-}\right]$maximum (Adkins \& Schrag, 2003).

The change of bottom water $\left[\mathrm{Cl}^{-}\right]$between the modern and LGM is inferred by adjusting the time-dependent bottom water chloride $\left[\mathrm{Cl}^{-}\right](\mathrm{t}, \mathrm{O})$ until the model output best fits the measured data (determined from Equation 2). We determine $\left[\mathrm{Cl}^{-}\right](\mathrm{t}, 0)$ by scaling global sea level (extending from the modern to $100 \mathrm{ka}$, Miller et al., 2015) to represent $\left[\mathrm{Cl}^{-}\right]$. The model output that best fits the measured $\left[\mathrm{Cl}^{-}\right](0, \mathrm{z})$ is determined by minimizing the sum of the squared differences between measured and model determined $\left[\mathrm{Cl}^{-}\right](0, z)$. The modeled $\left[\mathrm{Cl}^{-}\right](\mathrm{t}, 0)$ whose output $\left[\mathrm{Cl}^{-}\right](0, z)$ has the smallest square root of the sum of squared differences between it and the measured $\left[\mathrm{Cl}^{-}\right](0, z)$ is considered the mean $\left[\mathrm{Cl}^{-}\right](t, 0)$ for that site. To determine uncertainty in the model output, three $\left[\mathrm{Cl}^{-}\right](0, z)$ profiles are compared to the model output: the measured $\left[\mathrm{Cl}^{-}\right]$ $(0, z)$, or average; the measured $\left[\mathrm{Cl}^{-}\right](0, z)$ plus one standard deviation, or upper bound; and the measured 
Table 2

Index of Variables and Subscripts Used in This Study

\begin{tabular}{|c|c|c|}
\hline Symbol & Description & Unit \\
\hline$\rho$ & Density & $\mathrm{kg} / \mathrm{m}^{3}$ \\
\hline$M$ & Mass & $\mathrm{kg}$ \\
\hline$V$ & Volume & $\mathrm{m}^{3}$ \\
\hline $\mathrm{Ar}$ & Molecular mass & $\mathrm{kg} / \mathrm{mol}$ \\
\hline$V$ & Partial molar volume & $\mathrm{m}^{3} / \mathrm{mol}$ \\
\hline [ ] & Concentration & $\mathrm{mol} / \mathrm{L}$ \\
\hline$R$ & Ratio of bottom water concentration to $\left[\mathrm{Cl}^{-}\right]$ & - \\
\hline$a$ & Slope of $\left[\mathrm{Cl}^{-}\right]$versus density for standard seawater & $\mathrm{mol} / \mathrm{kg}$ \\
\hline$S$ & Salinity & $\mathrm{g} / \mathrm{kg}$ \\
\hline$\phi$ & Porosity & $\%$ \\
\hline$F$ & Formation factor & - \\
\hline$D$ & Free solution $\mathrm{Cl}^{-}$diffusion coefficient & $\mathrm{m}^{2} / \mathrm{sec}$ \\
\hline$z$ & Depth & mbsf \\
\hline$t$ & Time & sec \\
\hline$\Delta, \delta$ & Difference & varies \\
\hline$\partial$ & Partial derivative & varies \\
\hline meas & Measured variable & varies \\
\hline mod & Modeled variable & varies \\
\hline $\mathrm{H}_{2} \mathrm{O}$ & Pure water & - \\
\hline PW & Porewater & - \\
\hline BW & Bottom water & - \\
\hline$t_{[C l] \max }$ & Time of bottom water maximum $\left[\mathrm{Cl}^{-}\right]$ & $\sec$ \\
\hline$z_{[C l] \max }$ & Depth of porewater maximum $\left[\mathrm{Cl}^{-}\right]$ & mbsf \\
\hline
\end{tabular}

$\left[\mathrm{Cl}^{-}\right](0, \mathrm{z})$ less one standard deviation, or lower bound. The average model solution and its uncertainty for $\left[\mathrm{Cl}^{-}\right](0, z)$ and $\left[\mathrm{Cl}^{-}\right](t, 0)$ are the model $\left[\mathrm{Cl}^{-}\right](0, z)$ outputs identified as the best fits to the measured data \pm its uncertainty and their corresponding modeled $\left[\mathrm{Cl}^{-}\right](t, 0)$ inputs. A detailed description of the diffusion model is in the Supporting Information S1.

Inferred $\left[\mathrm{Cl}^{-}\right](t, 0)$ is converted to salinity $S$ with Equation 3 (see Table 2 for symbol definitions) (Lewis \& Perkin, 1978; Mcdougall et al., 2009; Millero et al., 2008).

$$
S=1.80655\left[C l^{-}\right] \frac{A r_{C l^{-}}}{\rho_{\mathrm{BW}}}
$$

\section{Results}

While the $\left[\mathrm{Cl}^{-}\right](0, z)$ output from the diffusion model has a maximum controlled by the maximum of the bottom water chloride model input $\left[\mathrm{Cl}^{-}\right]\left(t_{[\mathrm{Cl}] \mathrm{max}}, 0\right)$, the $\left[\mathrm{Cl}^{-}\right](0, z)$ profile's shape and the depth of the chloride max are affected more by the shape of the $\left[\mathrm{Cl}^{-}\right](\mathrm{t}, \mathrm{O})$ data set and the diffusion coefficient, respectively.

The shape of the $\left[\mathrm{Cl}^{-}\right](t, 0)$ data set depends on the sea level data used to estimate it. Here we use the scaled sea level compilation of Miller et al. (2015), as the $\left[\mathrm{Cl}^{-}\right](0, z)$ profile it produces when used as the model input is more similar to the measured profile than predicted modern profiles when other published sea level data are used as the input (Fairbanks \& Matthews, 1978; Shackleton \& Chappell. 1985; Siddall et al., 2003).

The depth below seafloor of the modern porewater chloride maximum $\left[\mathrm{Cl}^{-}\right]\left(0, z_{[\mathrm{Cl}] \mathrm{max}}\right)$ of the best-fit model output depends on (a) porewater and sediment physical properties, (b) the diffusion coefficient of seawater at the salinity and temperature of modern porewaters $D(z)$, and (c) the time of the bottom water chloride maximum $t_{[C l] \max }$. To maximize the precision of the diffusion model we measured $F(z)$ and $\Phi(z)$ rather than using an effective $D(z)$ that incorporates physical properties (Adkins \& Schrag, 2003). This difference in methodology can lead to systematic differences in inferred paleosalinities and is addressed in the Discussion. The $\left[\mathrm{Cl}^{-}\right]$ $\left(0, z_{[C l \text { max }}\right)$ varies by less than the modeled depth resolution of $0.5 \mathrm{~m}$ when $D(0)$ is adjusted to \pm 1 standard deviation of its published value. All best-fit model outputs are associated with the lowest of the three $D(0)$ $\mathrm{s}$ assessed at each site. We adjusted the timing of the maximum in the bottom water chloride data $\left[\mathrm{Cl}^{-}\right]\left(\mathrm{t}_{[\mathrm{Cl}]}\right.$ $\max , 0)$ to include its measured age of $21 \mathrm{ka}$ from Miller et al. (2015)'s global compilation and the additional ages of 19 and $25 \mathrm{ka}$ that represent the range of the observed LGM (Mix et al., 2001). At each site, the three best-fit model outputs include two different $t_{[C l] \max }$ (see Figure 2), confirming that $t_{[C l / \max }$ varies by location within the timing range of the LGM. The southern location (sites 03 and 10) reached its bottom water chloride maximum earlier than northern sites (11 and 12). Assessing a more robust family of differently timed and shaped $\left[\mathrm{Cl}^{-}\right](t, 0)$ inputs to the diffusion model will be necessary to further constrain this difference in timing by location.

The measured $\left[\mathrm{Cl}^{-}\right](0, z)$ profiles for each site are shown in Figure 2 along with best-fit $\left[\mathrm{Cl}^{-}\right](0, z)$ outputs from the diffusion model. Bottom water salinities for the modern $S(0,0)$ and LGM $S\left(t_{[C l] \max }, 0\right)$ are listed in Table 1 and shown in Figure 2. Inferred $S\left(t_{[C l] \max }, 0\right)$ are shown along with $S(0,0)$ versus latitude in Figure 3. Porewater salinities in the samples nearest the sediment-water interface $S(0,0)_{\text {meas }}$, based on smoothed measured values, are within $0.3 \%$ of the nearest WOCE $S(0,0)$ (Koltermann et al., 2011). Bottom water salinity change between the LGM and modern, $\Delta S\left(\left\{t_{[\mathrm{Cl}] \max }-0\right\}, 0\right)$, ranges from 1.202 to $1.403 \pm 0.05 \mathrm{~g} / \mathrm{kg}$, a 3.410 to $3.995 \pm 0.15 \%$ change relative to $S\left(t_{[C l] \max }, 0\right)$. 

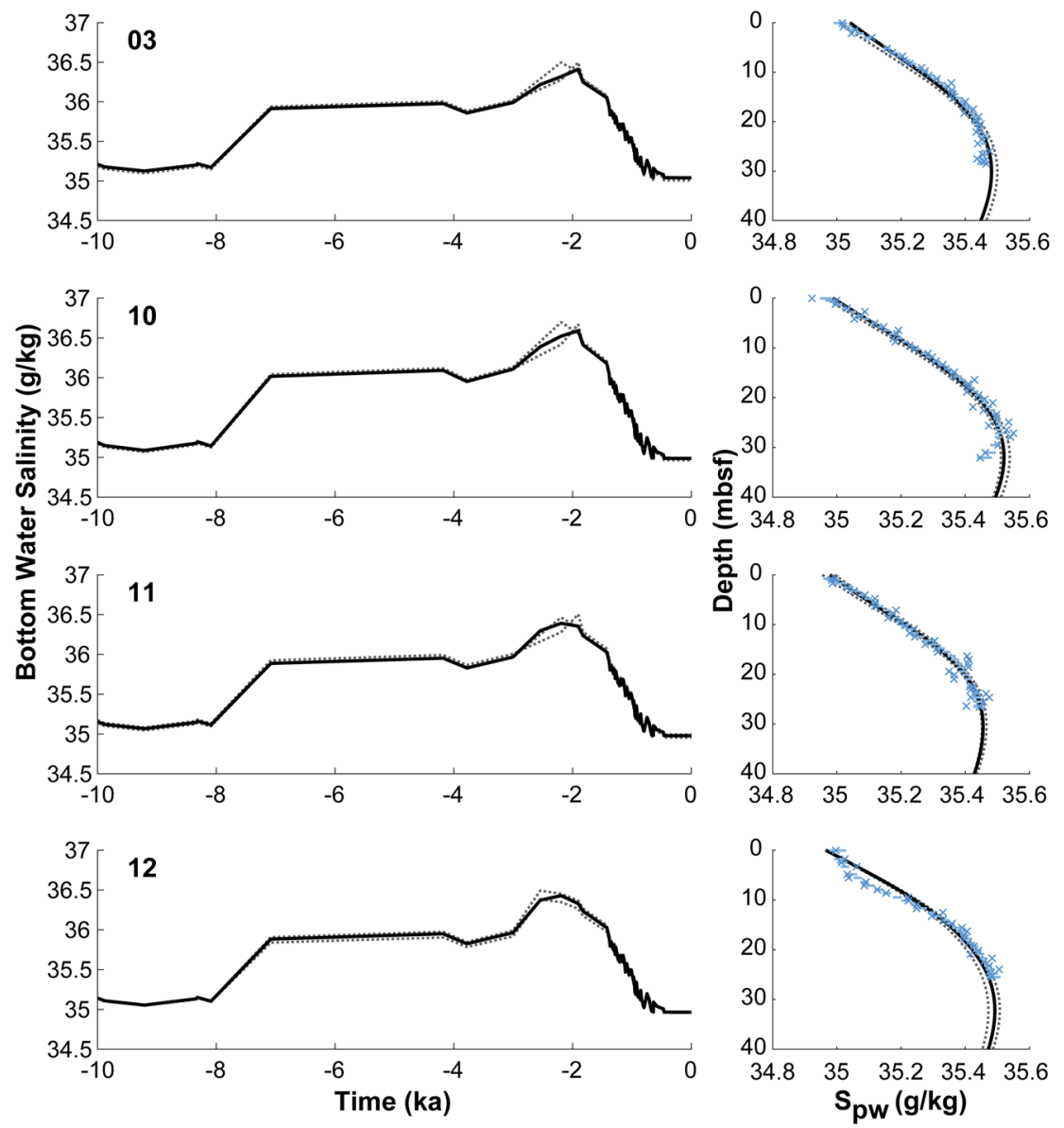

Figure 2. Diffusion modeled paleosalinity at all KN223 density sites (number on panel). Left panels show bottom water salinity used as the boundary condition for the model with porewater salinity that best fits the measured data (solid black line) and \pm one standard deviation (dashed grey lines). Right panels show porewater salinity profiles measured by density (blue x's) and their loess smoothed values and uncertainties (blue error bars, often obsured by symbols). The diffusion model that best fits the porewater data (solid black line) and \pm one standard deviation (dashed grey lines) at each site is also shown in the right panels.

\section{Discussion}

\subsection{Precision and Accuracy of LGM Reconstruction}

Using the density method of Homola et al. (2020), we infer LGM bottom water salinity $S\left(t_{[C l] \max }, 0\right)$ from measured $\left[\mathrm{Cl}^{-}\right](\mathrm{z}, 0)$ profiles that reach depths below seafloor shallower than any evaluated in previously published data. We report salinities with similar or improvised precision relative to the published results and double the number of sites in the Atlantic where LGM bottom water salinity has been inferred from measured subseafloor data. We focus on the change in $S$ between the modern and the LGM rather than the absolute $S$ during the LGM, as the paleosalinities inferred by this technique are more precise than they are accurate.

The precision and accuracy of this porewater-based paleosalinity reconstruction from a single core is primarily affected by three factors: (a) precision and accuracy of the measured $\left[\mathrm{Cl}^{-}\right](\mathrm{z}, 0)$ data, (b) spatial resolution of samples, and (c) length of core. The density-based method improves the precision of this study's results relative to published $\left[\mathrm{Cl}^{-}\right](\mathrm{z}, 0)$ data measured by $\mathrm{AgNO}_{3}$ titration onboard ship (Adkins \& Schrag, 2003; Homola et al., 2020; Insua et al., 2014). Accuracy of the study is in line with published paleosalinities, as salinity change inferred using the density method is consistent with the global average expected from sea level change $(3.6 \pm 0.3 \%)$ (Mix et al., 2001) (Table 1). Factor 2 was improved during this study as KN223 samples were collected at higher resolution both in terms of depth below seafloor ( $\sim 1$ mbsf between 

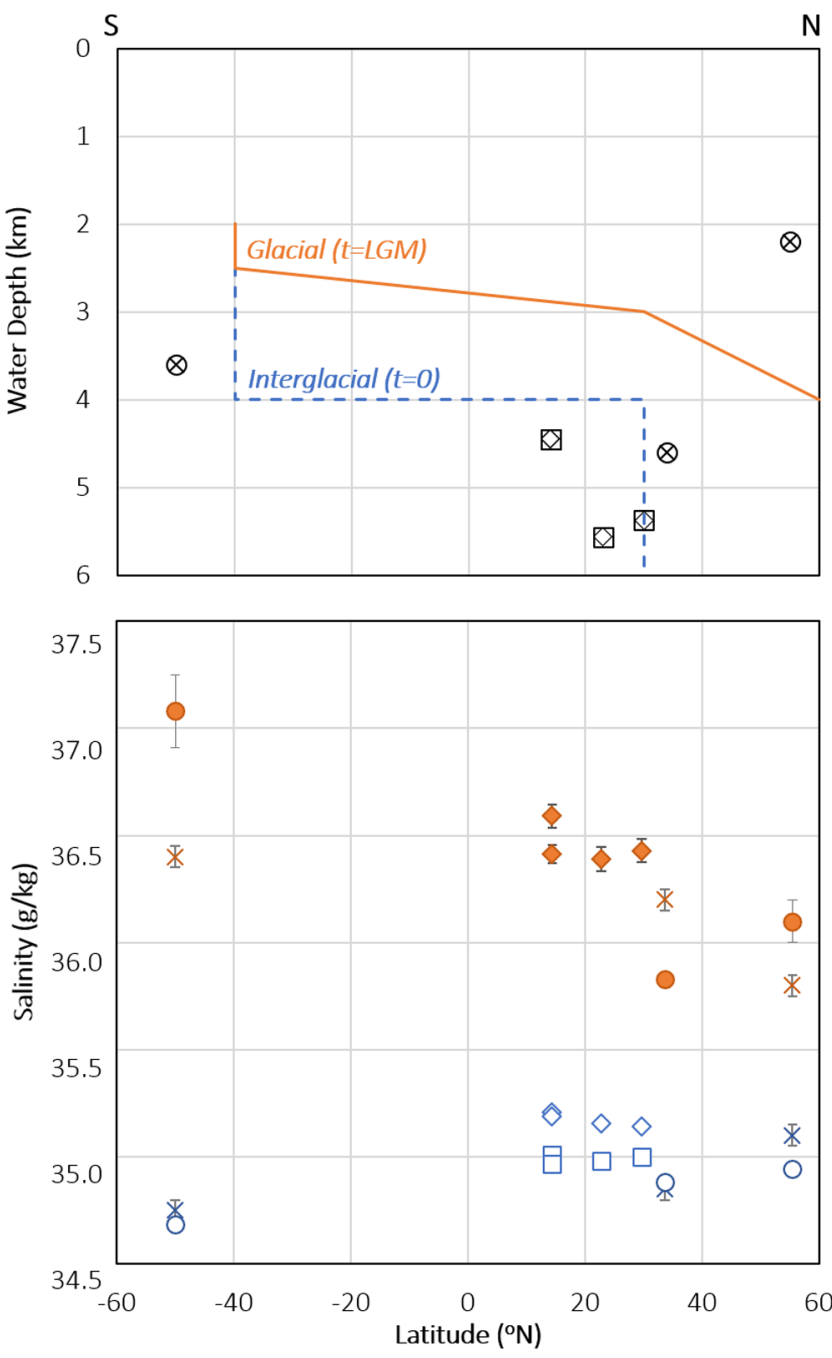

Figure 3. Atlantic water-mass distribution (top) and bottom water salinity (bottom) of the modern (blue) and reconstructed LGM (orange). Representative boundaries between northern and southern deep watermasses for the LGM (solid orange) and modern (dashed blue) determined from published LGM reconstructions (Adkins et al., 2005; Burke et al., 2015; Curry \& Oppo 2005; Galbraith \& de Lavergne, 2019; Insua et al., 2014; Lund et al., 2011; Lynch-Stieglitz et al., 2007) are included for the deep ocean (below $2 \mathrm{~km}$ ). Atlantic paleosalinity sites are shown on the top panel in black, distinguishing KN223 (diamonds within squares) from published (circles with x's) sites. Bottom water salinity values for the modern (open blue) and LGM (solid orange) are shown in the bottom panel: including measured (squares) and modeled (diamonds) results from the KN223 expedition; Galbraith and Lavergne (2019)'s modeling study (x's); and Adkins et al. (2002)'s titration measured data (circles). Uncertainty of each datapoint is included as a grey error bar, though many are obscured by symbols. analyzed porewaters samples) and water depth (cores measured in this study were collected from deeper locations than any previously published Atlantic paleosalinities) (Adkins et al., 2002). Along with adding three locations to the deep Atlantic $S\left(t_{[C l] \max }, 0\right)$ data set in the region of mixing between northern and southern overturning cells (Oppo et al., 2018), these sampling adjustments improve depth resolution, latitude resolution, and the evaluation of paleosalinity accuracy.

Paleosalinities inferred from cores that include results spanning the LGM porewater chloride maximum $\left[\mathrm{Cl}^{-}\right]\left(0, z_{[\mathrm{Cl}] \mathrm{max}}\right)$ with low sampling depth resolution or high analytical uncertainty are more accurate than paleosalinities inferred from cores that do not span $\left[\mathrm{Cl}^{-}\right]\left(0, z_{[\mathrm{Cl}] \mathrm{max}}\right)$, even if these shorter cores have higher resolution or higher precision. LGM paleosalinities determined from KN223 profiles that do not span $\left[\mathrm{Cl}^{-}\right]\left(0, z_{[\mathrm{Cl}] \mathrm{max}}\right)$ have similar precision to published profiles that do $\operatorname{span}\left[\mathrm{Cl}^{-}\right]\left(0, z_{[\mathrm{Cl}] \max }\right)$ (Adkins \& Schrag, 2003). These results indicate that paleosalinities with unprecedented accuracy and precision can be inferred from porewater samples collected from sites that span $\left[\mathrm{Cl}^{-}\right]\left(0, z_{[\mathrm{Cl}] \mathrm{max}}\right)$ and are analyzed shipboard with the density-based method.

\subsection{Salinity and Water-Mass Structure of the Deep Northwest Atlantic}

Published paleosalinity and benthic foraminiferal $\delta^{13} \mathrm{C}, \Delta^{14} \mathrm{C}$, and $\delta^{18} \mathrm{O}$ data (Adkins et al., 2002; Burke et al., 2015; Curry \& Oppo 2005; Govin et al., 2009; Insua et al., 2014; Keigwin, 2004; Keigwin \& Swift 2017; Lynch-Stieglitz et al., 2007; Oppo et al., 2018; Sijinkumar et al., 2016), contextualized by subsequent modelling studies (Clark et al., 2012; Cutler et al., 2003; Ferrari et al., 2014; Galbraith \& de Lavergne, 2019; Lund et al., 2011; Miller et al., 2012; Nadeau et al., 2019), indicate northern sourced Atlantic deep water shoaled and the southern MOC cell expanded northward during the LGM. This expansion of southern sourced deep water can account for two thirds of observed atmospheric $\mathrm{CO}_{2}$ decrease during the LGM through the excess of disequilibrium $\mathrm{CO}_{2}$ contained in glacial southern sourced deep waters (Brovkin et al., 2007; Skinner, 2009).

The observed $S\left(t_{[C l] \text { max }}, 0\right)$ from KN223 reported here and published data across different depths and latitudes (Adkins et al., 2005; Galbraith \& de Lavergne, 2019; Insua et al., 2014) support a northward expansion of salty southern sourced deep water that displaced fresher, northern sourced deep water during the LGM. The average inferred $S\left(t_{[\mathrm{Cl}] \mathrm{max}}, 0\right)$ is $36.46 \pm 0.05 \mathrm{~g} / \mathrm{kg}$ and the average $\Delta S\left(\left\{t_{[C l] \max }-0\right\}, 0\right)$ is $3.64 \%$ for all four western north Atlantic sites analyzed in this study. This inferred $S\left(t_{[C l]}\right.$ $\max , 0)$ is higher than both of the previously published values: $0.36 \mathrm{~g} / \mathrm{kg}$ higher than north Atlantic site ODP $981\left(55.48^{\circ} \mathrm{N}, 2,184 \mathrm{~m}\right)$ and $0.63 \mathrm{~g} /$ $\mathrm{kg}$ higher than western north Atlantic site ODP $1063\left(33.69^{\circ} \mathrm{N}, 4,584 \mathrm{~m}\right)$ (Table 1). These results are consistent with published results from an Earth-system coupled ocean, atmosphere, ice, biogeochemistry model of the glacial ocean (Galbraith \& de Lavergne, 2019). The difference between the KN223 north western Atlantic sites and ODP 1063 is likely due to the depth difference between sites, where KN223 sites are located 1,000 m deeper than ODP 1063. The shallower, more southern sites $\left(\mathrm{KN} 223-03\right.$ and 10 at $\left.14^{\circ} \mathrm{N}\right)$ in this study had a higher $S\left(t_{[C l] \max }, 0\right)$ than the two more northern sites $\left(\mathrm{KN} 223-11\right.$ at $23^{\circ} \mathrm{N}$ and $\mathrm{KN} 223-12$ at $\left.30^{\circ} \mathrm{N}\right)$ located $1,000 \mathrm{~m}$ deeper but with average $S\left(t_{[C l] \max }, 0\right) 0.1 \mathrm{~g} / \mathrm{kg}$ fresher. The differences in $S\left(t_{[C l] \max }, 0\right)$ with water depth in the western north Atlantic is supportive evidence of a strongly salinity stratified LGM deep Atlantic, where saltier deep water 
underlies fresher intermediate water. While these results support the literature consensus that the saltier deep water-mass in the north Atlantic is southern sourced, the strong vertical salinity gradient observed in the western north Atlantic could also be explained as fresher northern sourced intermediate water mixing with salty southern sourced deep water and salty northern sourced abyssal water (Keigwin \& Swift, 2017).

The modern deep Atlantic has a meridional salinity gradient with saltier bottom waters in the north and fresher bottom waters in the south (Koltermann et al., 2011; Talley, 2011). A potential reversal of this deep Atlantic meridional salinity gradient during the LGM, with saltier southern sourced waters underlying fresher northern sourced waters, has been described based on published paleosalinity data (Adkins $\&$ Schrag, 2001; Boyle 2002). The higher accuracy $S\left(t_{[C l] \max }, 0\right)$ results we report here are consistent with a deep LGM Atlantic salinity reversal but differ in magnitude from previously published data (Figure 3, Table 1). The average $S\left(t_{[C l] \max }, 0\right)$ inferred in this study is $0.58 \mathrm{~g} / \mathrm{kg}$ lower than previously published salinity determined at $50^{\circ} \mathrm{S}$ (ODP $1093,-49.98^{\circ} \mathrm{N}, 4,585 \mathrm{~m}$ water depth) by titration of stored samples (Adkins et al., 2002). Even the two KN223 sites in the western north Atlantic that lie deeper than 5,000 m, which are likely composed of mostly southern sourced deep water in the LGM (Oppo et al., 2018) have an average $S\left(t_{[C l] \max }, 0\right)$ higher than reported for the south Atlantic site ODP $1093\left(-49.98^{\circ} \mathrm{N}\right)$. As evaporation during storage imparts a consistent offset towards slightly higher $\left[\mathrm{Cl}^{-}\right](0, z)$ (Adkins \& Schrag, 2003; Homola et al., 2020), the inferred paleosalinity in the Southern Ocean from this single site (ODP 1093) may be higher than the true $S\left(t_{[C l] \max }, 0\right)$ of the southern sourced deep water. Our data is consistent with a Southern Ocean deep water-mass less salty than the published Southern Ocean value but higher in salinity than the measured north Atlantic value (ODP 981).

\subsection{Timing and Latitude of Southern Sourced LGM Bottom Water Expansion}

The timing of the LGM has been well examined and encompasses a 7,000 year period from 19 to $26 \mathrm{ka}$ (Mix et al., 2001; Peltier \& Fairbanks, 2006). While atmospheric and surface ocean chemical properties vary on similar, rapid timescales; deep ocean water-mass property changes that result from atmospheric or surface ocean changes are delayed by hundreds of years for well-traveled bottom waters (Lynch-Stieglitz et al., 2007; Marshall \& Speer, 2012; Schmittner et al., 2007). Thus, the onset and duration of maximum bottom water salinity $S\left(t_{[C l] \max }, 0\right)$ at a particular location during the LGM will likely vary by distance from bottom water formation regions.

The KN223 western North Atlantic sites have a $t_{[\mathrm{Cl}] \max }$ of $19 \pm 3 \mathrm{ka}$ at colocated KN223 southern North Atlantic sites (KN223-03,10; 14.4 $\left.{ }^{\circ} ; 4,453 \mathrm{~m}\right), 25 \pm 3 \mathrm{ka}$ at the northernmost KN223 sites $\left(29.7^{\circ} \mathrm{N}, 5,367 \mathrm{~m}\right)$, and $21 \pm 3 \mathrm{ka}$ for the site between these two $\left(22.785^{\circ} \mathrm{N}, 5,557 \mathrm{~m}\right)$. The inferred earlier onset of saltier southern sourced bottom water observed at southern relative to northern KN223 sites has high uncertainty (3,000 years) due to the depth differences and close locations of all sites in this study, along with the fact that $t_{[C l] \text { max }}$ is only evaluated at three separate locations. This analysis shows that systematic adjustment of the input $\left[\mathrm{Cl}^{-}\right]\left(t_{[\mathrm{Cl}] \max }, 0\right)$ and its fit to paleosalinity data merits further investigation, as it demonstrates potential to examine how the timing of the LGM bottom water salinity maximum differs by latitude.

The interface between northern and southern MOC cells in the deep Atlantic $(>2 \mathrm{~km})$ is identified using salinity, temperature, nutrient, and carbon isotope data (Figure 3). Highly resolved in the modern Atlantic, the interface between northern and southern sourced bottom water-masses (defined as 50\% northern sourced and $50 \%$ southern sourced) is located at $\sim 0^{\circ} \mathrm{N}$. While less constrained for the LGM, the timing and latitude of this MOC cell interface are key controls on the amount of carbon stored in the glacial deep Atlantic.

We use a simple global salt mass balance to examine the impact of the paleosalinities inferred in this study on global salinity change between the modern and LGM (see Supporting Information S1 for details). We combine a range of available data that define water-mass geometry (Adkins et al., 2005; Burke et al., 2015; Curry \& Oppo, 2005; Galbraith \& de Lavergne, 2019; Insua et al., 2014; Lund et al., 2011; Lynch-Stieglitz et al., 2007) to approximate the boundary between northern and southern MOC cells for the modern and the LGM (included for the Atlantic in Figure 3) and use the resulting cross-sectional areas to calculate zonally averaged volumes for the deep water-masses of the north Atlantic, south Atlantic, north Pacific, and south Pacific. We then use these volumes to calculate the deep ocean global average salinity for both 
the modern and LGM. We use these results to directly compare these two deep ocean salinities (Table S1) rather than using available, more comprehensive modern ocean salinity averages (Talley 2011; Worthington \& Wright, 1970) that may differ from LGM values simply because of differences in methodology. As the estimated deep Atlantic average LGM salinity depends on the $S\left(t_{[C l] \max }, 0\right)$ assumed for Southern Ocean, we use published inferred paleosalinity estimates, Earth-system modeled paleosalinity (Galbraith \& de Lavergne, 2019), and a combination of our data and the published data. When including data from this study, we calculate a $S\left(t_{[C l] \max }, 0\right)$ of $36.7 \mathrm{~g} / \mathrm{kg}$ using an Atlantic salinity mass balance and water-mass fractions determined from Oppo et al. (2018) (Figure S1). Global average salinity change between the modern and LGM is $4.26 \%$ when determined from the salt mass balance that includes data from this study, compared to $4.52 \%$ when determined from previously published data alone.

Improved latitude and depth resolution of paleosalinity data, especially in regions of deep water formation and mixing between northern and southern sourced deep waters, remains necessary to confirm the potential presence of northern sourced abyssal water (Keigwin \& Swift, 2017) and to further constrain the northward extent of the southern cell, the depth to which the northern cell shoaled during the LGM, and the timing of these changes in deep water-mass distribution.

\section{Conclusions}

We infer bottom water salinity during the LGM at four sites in the western North Atlantic with the recently developed high-precision density-based method. Measured porewater profiles were used to get a best estimate of LGM bottom water salinities by optimizing a time-dependent diffusion model of bottom water salinity over time (scaled from global sea level change). Bottom water salinity change between the modern and LGM, relative to LGM salinity, ranges from 3.41 to $3.99 \pm 0.15 \%$ when determined by density, consistent with global sea-level-informed salinity change. This result demonstrates the northward expansion of southern sourced deep water and the shoaling of northern sourced deep water during the LGM based on salinities at previously unsampled western North Atlantic sites measured using our high-precision density-based method. Although the LGM paleosalinities we determined by density measurement are lower than previously published paleosalinities determined by titration, our results support reversal of the Atlantic's north-south deep water salinity gradient during the LGM.

\section{Data Availability Statement}

All data used in this study is available in the EarthChem Library at https://doi.org/10.26022/IEDA/111472.

\section{Acknowledgments}

This study would not have been possible without the skill and input of Simon Engelhart and Dennis Graham. The authors give special thanks to Tania Lado Insua for providing the diffusion model protocol on which we based this study's model. They thank the scientists, crew, and coring technicians of R/V Knorr KN223 along with the University of Rhode Island Graduate School of Oceanography Biogeochemistry Lab Group. Reviews from Jess Adkins, Joris Geiskes, and an anonymous third reviewer were invaluable for focusing and clarifying the implications of these results. This work was supported by the US National Science Foundation (grant numbers 1433150 and 1537485).

\section{References}

Adkins, J. F., Ingersoll, A. P., \& Pasquero, C. (2005). Rapid climate change and conditional instability of the glacial deep ocean from the thermobaric effect and geothermal heating. Quaternary Science Reviews, 24, 581-594. https://doi.org/10.1016/j.quascirev.2004.11.005

Adkins, J. F., McIntyre, K., \& Schrag, D. P. (2002). The Salinity, temperature, and $\delta 180$ of the glacial deep ocean. Science, 298(5599), 1769-1773. https://doi.org/10.1126/science.1076252

Adkins, J. F., \& Schrag, D. P. (2001). Pore fluid constraints on deep ocean temperature and salinity during the last glacial maximum. Geophysical Research Letters, 28, 771-774. https://doi.org/10.1029/2000gl011597

Adkins, J. F., \& Schrag, D. P. (2003). Reconstructing last glacial maximum bottom water salinities from deep-sea sediment pore fluid profiles. Earth and Planetary Science Letters, 216(1-2), 109-123. https://doi.org/10.1016/s0012-821x(03)00502-8

Bouttes, N., Roche, D. M., \& Paillard, D. (2009). Impact of strong deep ocean stratification on the glacial carbon cycle. Paleoceanography, 24, 1-11. https://doi.org/10.1029/2008pa001707

Boyle, E. (2002). Oceanography: Oceanic salt switch. Science, 298(5599), 1724-1725. https://doi.org/10.1126/science.1079238

Boyle, E., \& Keigwin, L. (1982). Deep circulation of the North Atlantic over the last 200,000 years: Geochemical evidence. Science, 218, 784-787. https://doi.org/10.1126/science.218.4574.784

Brovkin, V., Ganopolski, A., Archer, D., \& Rahmstorf, S. (2007). Lowering of glacial atmospheric $\mathrm{CO}_{2}$ in response to changes in oceanic circulation and marine biogeochemistry. Paleoceanography and Paleoclimatology, 22, 1-14. https://doi.org/10.1029/2006pa001380

Burke, A., Stewart, A. L., Adkins, J. F., Ferrari, R., Jansen, M. F., \& Thompson, A. F. (2015). The glacial mid-depth radiocarbon bulge and its implications for the overturning circulation. Paleoceanography, 30, 1021-1039. https://doi.org/10.1002/2015pa002778

Clark, P. U., Dyke, A. S., Shakun, J. D., Carlson, A. E., Clark, J., Wohlfarth, B., et al. (2009). The last glacial maximum. Science, 325, 710-714. https://doi.org/10.1126/science.1172873

Clark, P. U., Shakun, J. D., Baker, P. A., Bartlein, P. J., Brewer, S., Brook, E., et al. (2012). Global climate evolution during the last deglaciation. Proceedings of the National Academy of Sciences of the USA, 109, 17-19. https://doi.org/10.1073/pnas.1116619109

Cleveland, W. S., \& Devlin, S. J. (1988). Locally weighted regression: An approach to regression analysis by local fitting. Journal of the American Statistical Association, 83, 596-610. https://doi.org/10.1080/01621459.1988.10478639 
Curry, W., Broda, J., Keigwin, L., Mountain, G., \& Pisias, N. (2008). A new long coring system for R/V Knorr. Eos Transactions American Geophysical Union, 89, 142-143. https://doi.org/10.1029/2008eo150002

Curry, W., \& Oppo, D. W. (2005). Glacial water mass geometry and the distribution of $\delta^{13} \mathrm{C}$ of $\Sigma \mathrm{CO}_{2}$ in the western Atlantic Ocean. Paleoceanography, 20, 1-13. https://doi.org/10.1029/2004pa001021

Cutler, K. B., Edwards, R. L., Taylor, F. W., Cheng, H., Adkins, J., Gallup, C. D., et al. (2003). Rapid sea-level fall and deep-ocean temperature change since the last interglacial period. Earth and Planetary Science Letters, 206. https://doi.org/10.1016/s0012-821x(02)01107-x

Divins, D. L. (2003). Total sediment thickness of the world's oceans and marginal seas. Boulder, CO: NOAA National Geophysical Data Center.

Doney, S. C., \& Schimel, D. S. (2007). Carbon and climate system coupling on timescales from the precambrian to the anthropocene. Annual Review of Environment and Resources, 32, 31-66. https://doi.org/10.1146/annurev.energy.32.041706.124700

Erbacher, J., Mosher, D. C., \& Malone, M. J. (2004). Leg 207. Proceedings of the ocean drilling program: International reports. https://doi. org/10.2973/odp.proc.ir.207.101.2004

Fairbanks, R. G., \& Matthews, R. K. (1978). The marine oxygen isotope record in Pleistocene coral, Barbados, West Indies. Quaternary Research, 10, 181-196. https://doi.org/10.1016/0033-5894(78)90100-x

Ferrari, R., Jansen, M. F., Adkins, J. F., Burke, A., Stewart, A. L., \& Thompson, A. F. (2014). Antarctic Sea ice control on ocean circulation in present and glacial climates. Proceedings of the National Academy of Sciences, 111. https://doi.org/10.1073/pnas.1323922111

Galbraith, E., \& de Lavergne, C. (2019). Response of a comprehensive climate model to a broad range of external forcings: Relevance for deep ocean ventilation and the development of Late Cenozoic ice ages. Climate Dynamics, 52, 653-679. https://doi.org/10.1007/ s00382-018-4157-8

Govin, A., Michel, E., Labeyrie, L., Waelbroeck, C., Dewilde, F., \& Jansen, E. (2009). Evidence for northward expansion of Antarctic bottom water mass in the Southern Ocean during the last glacial inception. Paleoceanography, 24, 1-14. https://doi.org/10.1029/2008pa001603

Graham, D. W., Corliss, B. H., Bender, M. L., \& Keigwin, L. D. (1981). Carbon and oxygen isotopic disequilibria of recent deep-sea benthic foraminifera. Marine Micropaleontology, 6, 483-497. https://doi.org/10.1016/0377-8398(81)90018-9

Holloway, M. D., Sime, L. C., Singarayer, J. S., Tindall, J. C., \& Valdes, P. J. (2016). Reconstructing paleosalinity from $\delta^{18}$ O: Coupled model simulations of the last glacial maximum, Last Interglacial and Late Holocene. Quaternary Science Reviews, 131, 350-364. https://doi. org/10.1016/j.quascirev.2015.07.007

Homola, K., Spivack, A. J., \& Murray, R. W. (2020). High precision paleosalinity determination from measured porewater density. Marine Chemistry, 226, 103868. https://doi.org/10.1016/j.marchem.2020.103868

Insua, T. L., Spivack, A. J., Graham, D., D'Hondt, S., \& Moran, K. (2014). Reconstruction of Pacific Ocean bottom water salinity during the last glacial maximum. Geophysical Research Letters, 41, 2914-2920. https://doi.org/10.1002/2014gl059575

Ito, T., \& Follows, M. J. (2013). Air-sea disequilibrium of carbon dioxide enhances the biological carbon sequestration in the Southern Ocean. Global Biogeochemical Cycles, 27. https://doi.org/10.1002/2013GB004682

Jansen, M. F. (2017). Glacial ocean circulation and stratification explained by reduced atmospheric temperature. Proceedings of the National Academy of Sciences of the USA, 114, 45-50. https://doi.org/10.1073/pnas.1610438113

Jansen, M. F., \& Nadeau, L.-P. (2016). The effect of Southern Ocean surface buoyancy loss on the deep-ocean circulation and stratification. Journal of Physical Oceanography, 46, 3455-3470. https://doi.org/10.1175/jpo-d-16-0084.1

Keigwin, L. D. (2004). Radiocarbon and stable isotope constraints on last glacial maximum and younger dryas ventilation in the western North Atlantic. Paleoceanography, 19, 1-15. https://doi.org/10.1029/2004pa001029

Keigwin, L. D., \& Swift, S. A. (2017). Carbon isotope evidence for a northern source of deep water in the glacial western North Atlantic. Proceedings of the National Academy of Sciences of the USA, 114, 2831-2835. https://doi.org/10.1073/pnas.1614693114

Kim, S. J. (2004). A coupled model simulation of ocean thermohaline properties of the last glacial maximum. Atmosphere-Ocean, 42, 213-220. https://doi.org/10.3137/ao.420305

Kobayashi, H., Abe-Ouchi, A., \& Oka, A. (2015). Role of Southern Ocean stratification in glacial atmospheric $\mathrm{CO}_{2}$ reduction evaluated by a three-dimensional ocean general circulation model. Paleoceanography, 30, 1202-1216. https://doi.org/10.1002/2015pa002786

Koltermann, K. P., Gouretski, V., \& Jancke, K. (2011). Hydrographic atlas of the world ocean circulation experiment (WOCE) volume 3: Atlantic Ocean. Southampton, UK: National Oceanography Centre.

Kwon, E. Y., Hain, M. P., Sigman, D. M., Galbraith, E. D., Sarmiento, J. L., \& Toggweiler, J. R. (2012). North Atlantic ventilation of southern-sourced deep water in the glacial ocean. Paleoceanography, 27, 1-12. https://doi.org/10.1029/2011pa002211

Lewis, E. L., \& Perkin, R. G. (1978). Salinity: Its definition and calculation. Journal of Geophysical Research, 83, 466. https://doi.org/10.1029/ jc083ic01p00466

Li, Y.-H., \& Gregory, S. (1974). Diffusion of ions in sea water and in deep-sea sediments. Geochimica et Cosmochimica Acta, $38,703-714$.

Lund, D. C., Adkins, J. F., \& Ferrari, R. (2011). Abyssal Atlantic circulation during the last glacial maximum: Constraining the ratio between transport and vertical mixing. Paleoceanography, 26, 1-19. https://doi.org/10.1029/2010pa001938

Lynch-Stieglitz, J., Adkins, J. F., Curry, W. B., Dokken, T., Hall, I. R., Herguera, J. C., et al. (2007). Atlantic meridional overturning circulation during the last glacial maximum. Science, 316. https://doi.org/10.1126/science.1137127

Manheim, F. T., Waterman, L. S., Woo, C. C., \& Sayles, F. L. (1974). 35. Interstitial water studies on small core samples, leg 23 (Red Sea) (pp. 955-967). Woods Hole, MA: Woods Hole Oceanographic Institution.

Marshall, J., \& Speer, K. (2012). Closure of the meridional overturning circulation through Southern Ocean upwelling. Nature Geoscience, 5, 171-180. https://doi.org/10.1038/ngeo1391

Matsumoto, K. (2017). Tantalizing evidence for the glacial North Atlantic bottom water. Proceedings of the National Academy of Sciences of the USA, 114, 2794-2796. https://doi.org/10.1073/pnas.1701563114

Mcdougall, T. J., Feistel, R., Millero, F. J., Jackett, D. R., Wright, D. G., King, B. A., et al. (2009). The international thermodynamic equation of seawater 2010 (TEOS-10): Calculation and use of thermodynamic properties. Intergovernmental Oceanographic Commission IOC of Unesco.

Miller, M. D., Adkins, J. F., Menemenlis, D., \& Schodlok, M. P. (2012). The role of ocean cooling in setting glacial southern source bottom water salinity. Paleoceanography, 27, 1-16. https://doi.org/10.1029/2012pa002297

Miller, M. D., Simons, M., Adkins, J. F., \& Minson, S. E. (2015). The information content of pore fluid $\delta^{18} \mathrm{O}$ and [Cl-]. Journal of Physical Oceanography, 45, 2070-2094. https://doi.org/10.1175/jpo-d-14-0203.1

Millero, F. J., Feistel, R., Wright, D. G., \& Mcdougall,T.J.(2008). The composition of standard seawater and the definition of the reference-composition salinity scale. Deep Sea Research Part I: Oceanographic Research Papers, 55, 50-72. https://doi.org/10.1016/j.dsr.2007.10.001

Mix, A., Bard, E., \& Schneider, R. (2001). Environmental processes of the ice age: Land, oceans, glaciers (EPILOG). Quaternary Science Reviews, 20, 627-657. https://doi.org/10.1016/s0277-3791(00)00145-1 
Müller, R. D., Sdrolias, M., Gaina, C., \& Roest, W. R. (2008). “Age, spreading rates, and spreading asymmetry of the world's ocean crust. Geochemistry, Geophysics, Geosystems, 9, 1-19. https://doi.org/10.1029/2007gc001743

Nadeau, L.-P., Ferrari, R., \& Jansen, M. F. (2019). Antarctic Sea ice control on the depth of North Atlantic deep water. Journal of Climate, 32, 2537-2551. https://doi.org/10.1175/jcli-d-18-0519.1

Negre, C., Zahn, R., Thomas, A. L., Masqué, P., Henderson, G. M., Martínez-Méndez, G., et al. (2010). Reversed flow of atlantic deep water during the last glacial maximum. Nature, 468, 84-88. https://doi.org/10.1038/nature09508

Oppo, D. W., Gebbie, G., Huang, K. F., Curry, W. B., Marchitto, T. M., \& Pietro, K. R. (2018). Data constraints on glacial atlantic water mass geometry and properties. Paleoceanography and Paleoclimatology, 33, 1013-1034. https://doi.org/10.1029/2018pa003408

Pälike, H., Lyle, M. W., Nishi, H., Raffi, I., Gamage, K., \& Adam, K. (2013). Expedition 320/321 scientists (2013): moisture and density (MAD) measured on IODP Hole 321-U1337B. PANGAEA. https://doi.org/10.1594/PANGAEA.824627

Peltier, W. R., \& Fairbanks, R. G. (2006). Global glacial ice volume and last glacial maximum duration from an extended Barbados sea level record. Quaternary Science Reviews, 25, 3322-3337. https://doi.org/10.1016/j.quascirev.2006.04.010

Petit, J. R., Jouzel, J., Raynaud, D., Barkov, N. I., Barnola, J.-M., Basile, I., et al. (1999). Climate and atmospheric history of the past 420,000 years from the Vostok ice core, Antarctica. Nature, 399, 429-436. https://doi.org/10.1038/20859

Pilson, M. E. Q. (2015). An introduction to the chemistry of the sea (p. 524). Cambridge University Press.

Robinson, A., \& Stommel, H. (1959). The oceanic thermocline and the associated thermohaline circulation. Tellus, 11, 295-308. https:// doi.org/10.3402/tellusa.v11i3.9317

Schmittner, A., Chiang, J. C. H., \& Hemming, S. R. (2007). "Introduction: The ocean's meridional overturning circulation. In A. Schmittner, J. C. H. Chiang, S. R. Hemming (Eds.), Ocean circulation: Mechanisms and impacts (pp. 6-9). https://doi.org/10.1029/173GM02

Schmittner, A., \& Galbraith, E. D. (2008). Glacial greenhouse-gas fluctuations controlled by ocean circulation changes. Nature, 456, 373376. https://doi.org/10.1038/nature07531

Shackleton, N. J., \& Chappell, J. (1985). The ocean deep water oxygen isotope record and the New Guinea sea level record. American Geophysical Union Transcripts, 66, 293.

Siddall, M., Rohling, E. J., Almogi-Labin, A., Hemleben, C., Meischner, D., Schmelzer, I., \& Smeed, D. A. (2003). Sea-level fluctuations during the last glacial cycle. Nature, 423(6942), 853-858. https://doi.org/10.1038/nature01690

Siegenthaler, U., Stocker, T. F., \& Monnin, E. (2005). Stable carbon cycle-climate relationship during the Late Pleistocene. Science, 310, 1313-1317. https://doi.org/10.1126/science.1120130

Sigman, D. M., \& Boyle, E. A. (2000). Glacial/interglacial variations in atmospheric carbon dixoide. Nature, 407, 859-869. https://doi. org/10.1038/35038000

Sigman, D. M., Hain, M. P., \& Haug, G. H. (2010). The polar ocean and glacial cycles in atmospheric $\mathrm{CO}_{2}$ concentration. Nature, 466, 47-55. https://doi.org/10.1038/nature09149

Sijinkumar, A. V., Clemens, S., Nath, B. N., Prell, W., Benshila, R., \& Lengaigne, M. (2016). $\delta^{18}$ O and salinity variability from the Last Glacial Maximum to recent in the Bay of Bengal and Andaman Sea. Quaternary Science Reviews, 135, 79-91. https://doi.org/10.1016/j. quascirev.2016.01.022

Skinner, L. C. (2009). Glacial-interglacial atmospheric CO2 change: A possible "standing volume" effect on deep-ocean carbon sequestration. Climate of the Past, 5, 537-550. https://doi.org/10.5194/cp-5-537-2009

Talley, L. (2011). Descriptive physical Oceanography: An introduction (p. 320). Elsevier.

Talley, L. D., Feely, R. A., Sloyan, B. B., Wanninkhof, R., Doney, S. C., Fine, R. A., et al. (2015). Changes in ocean heat, carbon content, and ventilation: A review of the first decade of GO-SHIP global repeat hydrography. Annual Review of Marine Science, 8, 185-215. https:// doi.org/10.1146/annurev-marine-052915-100829

Worthington, L. V., \& Wright, W. R. (1970). North Atlantic Ocean atlas of potential temperature and salinity in the deep water including temperature, salinity and oxygen profiles from the Erika Dan Cruise of 1962 (p. 77). Woods Hole Oceanographic Institution.

Wunsch, C. (2016). Pore fluids and the LGM ocean salinity-reconsidered. Quaternary Science Reviews, 135, 154-170. https://doi. org/10.1016/j.quascirev.2016.01.015

Zachos, J., Pagani, H., Sloan, L., Thomas, E., \& Billups, K. (2001). Trends, rhythms, and aberrations in global climate 65 Ma to present Science, 292, 686-693. https://doi.org/10.1126/science.1059412

\section{Reference From the Supporting Information}

Boudreau, B. P. (1997). Diagenetic models and their implementation (p. 414). Berlin: Springer. 